\title{
New framework of child-friendly living in high-rise housing
}

\author{
Z. Y. Sitiayu, H. Khadijah \& T. Zurinah \\ Department of Real Estate, Faculty of Geoinformation and Real Estate, \\ Universiti Teknologi Malaysia, Malaysia
}

\begin{abstract}
High-rise buildings are in high demand among many types of housing in the country that cater for the current needs and demands. The statistics show an increasing number of incidences where children fall from high-rise residences such as flats and condominiums. These incidences not only resulted in injury, but there has also been cases of deaths. Such sad occurrences are in fact avoidable. They should not occur, even more so where children are involved. Unfortunately, these events have taken place because the designs of many high-rise buildings lack the necessary safety features. The safety aspect needs to be emphasized in the design of high-rise buildings, especially with regard to child safety. In this connection, physical features related to comfort, security, and adequate access to recreational areas would help prevent tragedies of children falling, while allowing provisions for emergencies and crime prevention measures. The need for proper planning in the physical aspects of housing designs that offer a safe environment should be impressed upon local authorities, housing developers and parents so that cases of children falling from high-rises would not recur. This paper presents a framework and guidelines for the comprehensive planning of high-rise buildings to ensure the incorporation of physical features conducive to child safety.

Keywords: high-rise buildings, quality, children friendly, framework.
\end{abstract}

\section{Introduction}

Sustainable development has been defined in various ways, but it is best seen in terms of the direction that development takes against a global backdrop of "our common future". "Sustainable development" is a development that meets the current needs, without compromising the ability of next generations to meet their 
own needs [1]. The concept of sustainable development could be interpreted in a different way which is, at its core, an approach to development that looks towards balancing different, and often, competing necessity while inculcating an awareness of how they might impact the environmental, social and economic frailties of the planet $[2,3]$. Sustainable development as a process that brings together three crucial factors: (i) ecological - to live within the carrying capacity of the earth's biophysical while maintaining biodiversity; (ii) social - to ensure the development of democratic systems of governance to deploy and maintain the values that people wish to live well; and (iii) economic - to ensure that basic needs are met worldwide [3].

The housing sector, "sustainable housing" is a concept that is relatively new in some developing countries, and undertaking research that covers all aspects of sustainability has proven to be difficult [4]. Sustainable housing can be defined as housing practices aimed at attaining integral quality that encompasses the broad aspects of economic, social, and environmental well-being [5, 6]. Sustainable housing has features by minimize the environmental impacts of the use of material as well as energy and water consumption during the service life of the building [6]. The focus on sustainable housing would necessarily entail an in-depth look at the development of affordable housing with regard to human and social needs, planning rules, resource regeneration, sustainable construction, and best practices in the housing sector.

Sustainable housing development, especially in congested urban areas where space is limiting, is increasingly trending towards high-rise construction. After a phase of intermittent rejection in the mid-1970s, multi-storey housing, as the most compact housing design, has been re-accepted as a solution for sustainable housing by many expertise such as policy makers, developers, planners, and designers worldwide [7-9]. Many stakeholders in housing development schemes today believe high-rise living to be a sustainable form of housing that has many positive aspects from the viewpoint of sustainability, not the least of which is lower land consumption [10].

Other advantages of high-rise community living include higher energy efficiency [11, 12], lower resource consumption [13, 14], and improved accessibility to services and facilities [15]. Further benefits lie in the privacy and quietness afforded by high-rise residences, as well as the scenic view from the upper floors [16]. Even so, a sustainable future here would necessarily require an injection of a slew of reforms to improve the efficiency and effectiveness of affordable social housing before a secure and livable environment can be promised. Current housing development is often deficient in safety features, especially where it concerns the needs of children. Inadequate infrastructure, social amenities, and utilities could have a negative influence on growing children living in high-rises, and on the quality of life for residents in general.

\section{Development in high-rise housing estates}

Environmental sustainability that includes housing development is a process which looks into the deployment of natural resources for livable space. Housing 
development has significant implications for the pursuit of urban sustainability as housing is one of the most important components of the built environment. Highrise housing lifestyle is now recognized and accepted as a global phenomenon. Although the final forms of high-rise buildings are the result of complex planning and processes that take into consideration elements of cultural, social, and economic influences, the underlying principles common to urbanism, engineering, and architecture are employed in each case [17].

Two key concepts regarding sustainable development, viz. the concept of 'needs', especially the essential necessity of the world's poor to which preference should be accorded and secondly, the environment's capacity to accommodate present and future necessity in view of the limitations imposed by the state of technology and social organization [1]. Although this report is primarily concerned with securing global equity through the redistribution of resources to developing nations while encouraging economic growth, it remains relevant to housing needs. In fact, close to half the recognized indicators of sustainable development in this report are related to housing; these indicators are a part of the housing agenda to achieve comprehensive development that incorporates environmental protection, economic growth, and social equity.

Sustainable housing is also concerned with the delivery of sustainable neighborhoods and the need to address related issues such as employment, health, transport, education, and safety. The objectives of sustainable housing are to build low-energy, environment-friendly buildings that provide better comfort to the occupants and enable them to enjoy an acceptable quality of life while conserving resources for the future generations. In this regard, an improved quality of life means a higher standard of living, usually to ensure in terms of income level and the rational use of resources and technology. Inherent in the concept of sustainable development is the principle of equity while striving to achieve economic, environmental, and social goals.

\section{Sustainable design of residential high-rise buildings}

In many Western countries, the construction of multi-stories buildings had sharply declined or ended by the 1970s. While in Asian and Eastern European countries these kinds of residential properties have continued to be built. Within a decade in many western countries, the shift from new building construction to repair, upgrading and reuse was significant [18].

High-density living and particularly inner city high-rise living, is associated with lower physical activity, behavioral problem, infrastructure problems and social isolation. Residing in populated high-rise developments can be advantageous as there is an availability of a variety of adults and children with whom to interact, and there are also disadvantages of such environments are noise, people overload and security problems [19].

Higher density housing or high-rise housing estate can be an effective way to solve the problem of scarce land resources; make more efficient use of existing infrastructure; reduce the necessity of travel by providing local amenities; reduce 
the reliance on car transport by providing a focus for pedestrian, cycling and public transport integration [1].

Residential high-rise buildings describe the most critical building types with regard to developing a livable city and a healthy for sustainable community. The way we live impact all the other functions of daily life, the condition and quality of the habitation especially infrastructure of high-rise building directly impact the vitality of neighborhoods, communities, and urban living in general. Quality of developing are the largest and affordable housing, diverse populations in urban centers have been a goal of architects and planners for a long time. Recently they have begun to consider the importance of sustainability in high-rise residential building as a determinate of urban development and the livable city [20]. Highrise residential estates should cater to the wellbeing of a community that values personal security, adequate supporting infrastructure, comfort, and the mental and physical health of its residents. These characteristics could serve as parameters of sustainability.

High-rise residential are crucial to consider the sustainable design of the cities and communities. While not everyone needs to live in high-rise buildings, it is become a necessity for people over the world. Especially in cities and countries because land is expensive, limited, population and urban density [20,21].

Due to the impact of occupancy, there are needs of solutions in high-rise housing development for a better life. Many criteria are used generally to all buildings can be used to determine the design of sustainable high-rise residential buildings include physical, social and economic aspects.

Figure 1 shows an integrated approach to the optimum solution in high-rise building. To reach the sustainable housing development for high-rise residential, the environment need to consider the main criteria, which is a physical, social and economic aspect. The safety aspect including design and features of the building for occupancy are considered under the physical aspect.

\section{Framework for child-friendly high-rise housing}

Theoretical framework of this paper focuses on high-rise buildings in developing countries particularly for Malaysia. Community oriented design for sustainability in architecture, structure and safety planning in high-rise building [22] and focus on social issues [23] is to guarantee comprehensive approach toward environmental and sustainability development and meet eco-friendly design and the concept of comprehensive planning for livability of high-rise housing estates for children friendly [23]. Developing countries such as Malaysia require a comprehensive approach to this more than other parts of the world $[23,24]$. The framework should outline the steps the government must take to create a more sustainable design in high-rise housing system that supports the most vulnerable now and in the future. It undertook to create a better society, provide better opportunities to the tenant and developing better social housing assets. It seems that the redevelopment plans in a formal document are more eco-friendly than the real perspectives including safety building code and planning standard for safety infrastructure in high-rise building especially for children. 


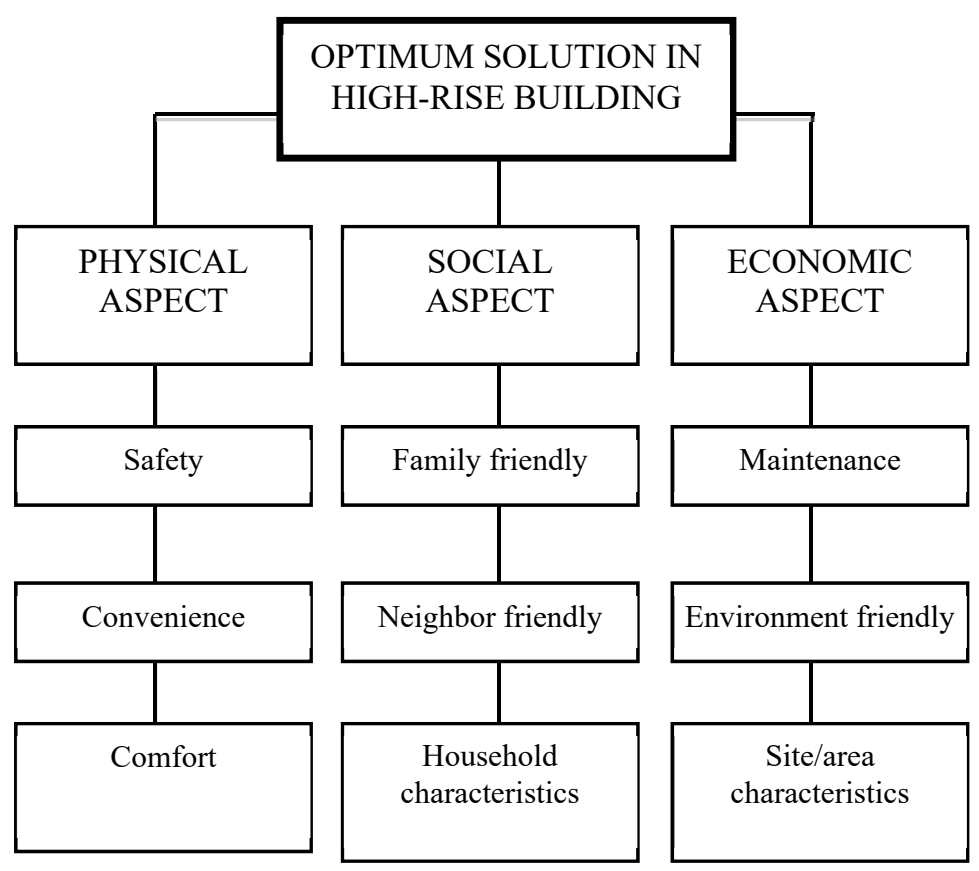

Figure 1: An integrated approach to optimum solution in high-rise building.

Play areas for children, both indoors and outdoors, are an important consideration in the planning of housing since play is essential for children's development $[25,26]$. On one hand, a link was established between the environmental quality of play, the health and social outcomes in later life [25]. On the other hand, constrained indoor limited space for children's ability to undertake various activities on their own or in groups [27]. Access restriction to play areas for children living in high density properties is hence a matter of concern.

The inability of parents or caretakers to supervise children is a problem [28] in situations where the children are either restricted because they are not allowed to play outside unsupervised [19], or because of safety concerns [29, 30]. Number of challenges facing opportunities for play among children and youths in high density housing. For the housing industry, how these challenges are addressed reflects the industry's understanding and commitment to social sustainability, especially where it concerns the welfare of children [31]. The attitude the industry has taken in recent years marks an important shift in its focus towards long-term stewardship in new high-rise housing developments. The issues present day housing developers need to grapple with include (i) the absence of direct outdoors access apart from the balcony, where safety is limited for toddler; (ii) children who need 


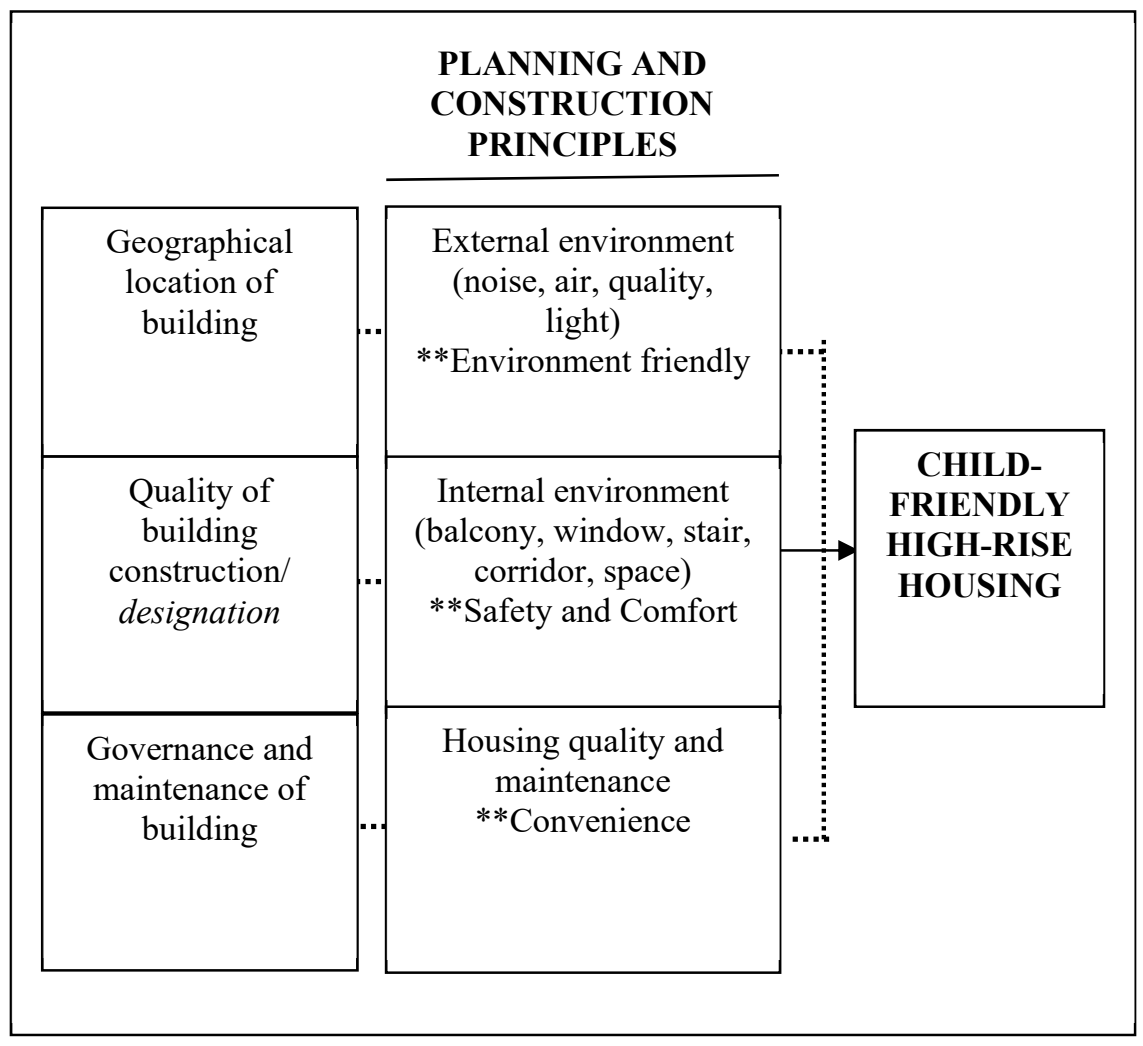

Figure 2: $\quad$ Framework for child-friendly high-rise housing [8].

adult to help when using elevators; (iii) issues related to supervision of children in outdoor activities; (iv) a high degree of sound transmission between units; (v) a lack of family-oriented amenities with a range of off-limits to children and adolescents; and (vi) limited land available for play areas.

Many solutions have been proposed to make high density housing building more responsive to the needs of children. There are several number of simple design solutions that make it easier for children to have access to play areas and thus enjoy a better quality of life. The design of tall buildings must improve to allows direct supervision of play areas by adults [31] either when the adults are inside and the children outside, or provides ample outdoor play area with spaces for parents to sit and socialize. There are also other important design considerations pertaining the child safety, including the design and construction of balcony balustrades and windows to avoid child falls. There should also be appropriate lighting and monitoring facilities, both passive and active [30]. Live in a well-designed and well-constructed high-rise building with good neighborly relationships will have a positive influence on both the physical and mental health 
of residents. Vice versa, poor social relations and poorly designed and constructed buildings can have ravaging effects.

With regard to appropriate spaces and facilities, overcrowding and lack of privacy that leads to emotional stress and strained family relationships have been identified as a problem peculiar to children occupancy in high-rise [26-28]. Design considerations with respect to families with children should also take into account the diversity of families with children, and the very different needs of children of different ages, "especially if housing is to accommodate them as they progress through different stages in the life cycle and thus have different needs" $[30,32]$. Planners and residents should take pro-active action to address problems in high-density living. This is because as an environment of poor housing design and construction quality, coupled with unamicable social relations, can cause residents experiencing isolation, stress, anxiety for safety (whether due to concerns about other residents, or due to a lack of passive surveillance), and disruptions to the quiet enjoyment of the homes. This could further lead to health problems (for example due to unsatisfactory ventilation or insufficient outdoor space), lack of privacy, disturbed sleep, and adequate safety space (indoor space) for children.

\section{Conclusion}

This paper explores the building industry framework for child-safe high-rise housing in Malaysia. It discusses the harmonization of key aspects in the framework that would contribute to the sustainable development of the highrise building sector. Many of the issues facing residents in high-rises are related to safety for children. In this report, we describe how social relationships can be either tense or strengthened as a result of living in close to other residents, and how the design and construction of a building have a major impact on social relations. In fact, not only mix of residents important in influencing social relations in high-density developments, but also the interactions among resident strongly affected by both building design and construction quality. Good building planning, design and construction thus play a significant role in the quality of high-rise living, especially for young residents who need adequate space for recreation.

\section{References}

[1] Brundtland Report (WCED) 1987. The Brundtland Report, Our Common Future.

[2] Dale, A. 2001. At the Edge: Sustainable Development in the 21st Century. Vancouver: UBC Press.

[3] Ann Dale \& Lenore L. Newman 2014. Sustainable development for some: green urban development and affordability. Local Environment: The International Journal of Justice and Sustainability.

[4] Ebsen C., Ramboll B. 2000. International Review of Sustainable Low-Cost Housing Projects Proceedings: Strategies for a Sustainable Built Environment, Pretoria, 23-25 August 2000. 
[5] John G., Croome D.C. and Jeronimidis G. 2005. Sustainable building solutions: a review of lessons from the natural world. Building and Environment, 40(3): 317-326.

[6] Abu Hassan Abu Bakar, Arman Abd Razak, Shardy Abdullah and Aidah Awang 2009. Project Management Success Factors For Sustainable Housing: A Framework. School of Housing, Building and Planning, Universiti Sains Malaysia, Pulau Pinang, Malaysia.

[7] Yeh A.G.O. \& Yuen B. 2011. Introduction: High-rise Living in Asian Cities. High-rise Living in Asian Cities. London: Springer.

[8] Turkington R., Kempen R.V. et al. 2004. High-rise housing in Europe: Current trends and future prospects, Delft, Delft University Press.

[9] Li Chenguang 2012. Liveability of High-rise Housing Estates 48th ISOCARP Congress.

[10] Jenkins P., Smith H. et al. 2007. Planning and housing in the rapidly urbanising world London, Routledge.

[11] Travers T. 2001. Density Means Better City. Cities for the New Millennium. London: Spon Press.

[12] Lau S., Wang J. et al. 2005. High-density, High-rise and Multiple and Intensive Land Use in Hong Kong: A Future City Form for the New Millennium. Future Forms and Design for Sustainable Cities. Oxford: Architecture Press.

[13] Barter P.A. 2000. Transport Dilemmas in Dense Urban Areas: Examples from Eastern Asia. Compact Cities: Sustainable Urban Forms for Developing Countries London: Spon Press.

[14] Kaji H. 2001. Compact City and Sustainable Urban Form: Is Compact City Approach Appropriate as an Urban Development Policy for Cities in Developing Countries?

[15] Kaido K. 2005. Urban Densities, Quality of Life and Local Facility Accessibility in Principle Japanese Cities. Future Forms and Design for Sustainable Cities. Oxford: Architecture Press.

[16] Yuen B., Yeh A. et al. 2006. "High-rise Living in Singapore Public Housing". Urban Studies, 43.

[17] Mohammad Javad Mahdavinejad, Ali Sadraie, Golrokh Sadraie 2014. Social Sustainability of High-rise Buildings. Journal of Social Economics Research, 2014, 1(2): 9-19.

[18] Roderick J. Lawrence 2009. Healthy Cities and Housing: Key Principles for Professional Practices, Workshop Engineering Solutions for Sustainability Materials and Resources, EPFL (Lausanne, CH), 22 juillet 2009.

[19] Churchman A. and Ginsberg Y. 1984. "The Image and Experience of Highrise Housing in Israel.” Journal of Environmental Psychology, 4: 27-41.

[20] Mir M. Ali \& Paul J. Armstrong 2008. Green Design of Residential HighRise Buildings in Livable Cities. IBS/NAHB Symposium, Orlando, FL, Feb 13-16.

[21] Beedle L., Ali M.M. and Armstrong P.J. 2007. The Skyscraper and the City: Design, Technology, and Innovation, Edwin Mellen Press, Lewiston, NY. 
[22] Mahdavinejad M. and M. Abedi 2011. Community-oriented landscape design for sustainability in architecture and planning. Procedia Engineering, 21: 337-344.

[23] Mahdavinejad M., M. Bemanian, M. Hajian and P. Pilechiha 2012a. Usage of indigenous architectural patterns for manufacturing industrial housing, case: Renovation project of Odlajan of Tehran, Iran, Advanced Materials Research, 548: 875-879.

[24] Chiesura A. 2004. The role of urban parks for sustainable city. Landscape and Urban Planning: 129-138.

[25] Beer A. 2003. The art of making people friendly places. Online presentation. Available at: http://www.thesteelvalleyproject.info/green/ Places/index.htm. Last updated 7 March 2007. Accessed 23 March, 2010.

[26] Evans G. 2006. "Child Development and the Physical Environment." Annual Review of Psychology, 57: 423-451.

[27] Sarkissian W. and Kerr A. 2003. High-Density Dwelling Design for Children. Mirvac Fini: Burswood lakes. Sarkissian Associates Planners, West End, QLD.

[28] Appold S. and Yuen B. 2007. "Families in Flats, Revisited." Urban Studies, 44(3), pp. 569-589.

[29] Mitchell R. 1971. "Some Social Implications of High Density Housing." American Sociological Review, 36(1): 18-29.

[30] Hazel Easthope and Sarah Judd 2010. Living well in greater density. Shelter Brief 42 ISSN 1448-7950

[31] Yates R. 1995. Child Friendly Housing: A Guide for Housing Professionals. Society for Children and Youth of British Columbia, Vancouver.

[32] Fincher R. 2007. "Is High-rise Housing Innovative? Developers' Contradictory Narratives of High-rise Housing in Melbourne", Urban Studies, 44(3): 631-649.

[33] Aregger H. \& Glaus O. 1967. High-rise building and urban design, FA Praeger, 1967.

[34] Billie Giles-Corti, Kate Ryan, Sarah Foster 2012. Increasing density in Australia: maximising the health benefits and minimising harm.

[35] Conway J. \& Adams B. 1977. The social effects of living off the ground. Habitat International, 2, 595-614.

[36] Cooper Marcus C. \& Hogue L. 1976. Design guidelines for high-rise housing. Journal of Architectural Research, 5, 34-49.

[37] Broyer G. 2002. The appropriateness of buildings over 20 storeys high for middle-class residents. Research thesis, Technion, the Israeli Institute of Technology.

[38] Cohen S., Glass D.C. \& Singer J.E. 1973. Apartment noise, auditory discrimination, and reading ability in children. Journal of Experimental Social Psychology, 9, 407-422.

[39] Conway Donald J. 1977. Human response to tall building. Hutchinston and Ross Inc, 1977.

[40] Gittus E. 1976. Flats, families, and the under-fives. London: Routledge \& Kegan Paul. 
[41] Mahdavinejad M., M. Mashayekhi and A. Ghaedi 2012b. Designing communal spaces in residential complexes. Procedia Social and Behavioral Sciences, 51: 533-539.

[42] Moore W. 1969. The vertical ghetto. New York: Random House.

[43] Niam Chiang Meng \& John Keung Kam Yin 2004. Improving the Hardware, Retaining the Heartware - The Singapore Way to Sustainable Housing. Housing \& Development Board, Singapore.

[44] Oda M., Taniguchi K., Wen M.-L. \& Higurashi M. 1989. Effects of highrise living on physical and mental development of children. Journal of Human Ergology, 18, 231-235.

[45] Oke M., Khattar A., Pant P. \& Saraswathi T.S. 1999. A profile of children's play in urban India. Childhood: A Global Journal of Child Research, 6, 207219. SB08 Hong Kong Report, 2008: 5.

[46] Robert Gifford 2006. The Consequences of Living in High-Rise Buildings. Architectural Science Review Volume 50.1.

[47] Wang Xu \& Lau Siu Yu 2002. Pursuing New Urban Living Environment in The New Millennium: Projecting The Future of High-Rise and High Density Living in Hong Kong - Generative Art 2002.

[48] Yuen Belinda, Gar-On Yeh 2011. High-Rise Living in Asian Cities. ISBN 978-90-481-9738-5. 